\title{
MANAGEMENT OF ILEAL PERFORATION USING APACHE - II SCORING: A PROSPECTIVE STUDY
}

\author{
Gaurav Agrawal' ${ }^{1}$ Megha Mittal' ${ }^{2}$ Amit Agrawal 3 , K. K. Agrawal ${ }^{4}$
}

${ }^{1}$ Consultant, Department of Surgical Oncology, BIMR Oncology Centre, Gwalior.

${ }^{2}$ Assistant Professor, Department of Radiodiagnosis, GR Medical College, Gwalior.

${ }^{3}$ Resident, Department of Radiotherapist, SRMS Hospital, Bareilly.

${ }^{4}$ Consultant, Department of Oncology, BIMR Oncology Centre, Gwalior.

\begin{tabular}{l}
\hline ABSTRACT \\
BACKGROUND \\
Peritonitis resulting from small bowel perforation is a frequently encountered surgical problem in India. A review of literature \\
indicates a very high mortality associated with this condition in spite of advances in treatment. The management of ileal perforation \\
has been a subject of controversy. Operative treatment has been generally accepted as the treatment of choice, but the choice of \\
procedure continues to be debated.
\end{tabular}

\section{AIMS AND OBJECTIVES}

In this we will study the patient factors responsible for poor outcome independent of or in association with APACHE II scoring. We will compare the outcomes of different methods of treatment.

\section{MATERIAL AND METHODS}

This is a prospective study of 60 patients of surgically verified ileal perforation treated in J. A. Group of Hospitals, Gwalior, during 1.08.2005 to 31.07.2006. The patients were categorised into three risk groups that is low risk, intermediate risk and high risk according to APACHE II scoring system. The low risk group were managed by surgery without faecal diversion (ileostomy). The intermediate risk were managed by surgery with faecal diversion (ileostomy). Since in high risk group patients could not undergo immediate laparotomy, they were managed medically first and then subjected to further management.

\section{RESULTS}

APACHE II score provides the extent of physiology derangement and preadmission chronic health of a patient with intraabdominal sepsis. Thirty patients (50\%) had score below 10 (low risk group). Simple closure of perforation was done in 24 patients and resection anastomosis was done in 6 patients. Twenty six patients had a score in between 11-20 (Intermediate risk group). In all of them, ileostomy with distal mucus fistula was made. All of them recovered satisfactorily. Four patients had a score of more than 20 (High risk group). In all of them, bilateral flank drainage was done under local anaesthesia. All of them died over a period of few days. Main postoperative complications were wound infection $43.3 \%$ and burst abdomen $23 \%$. Biopsy of ileal segment was performed in 46 cases. Thirty cases $(65.21 \%)$ showed acute enteritis, 12 cases $(26.08 \%)$ showed chronic nonspecific inflammation and 4 cases (8.69\%) showed epithelioid granuloma with caseation.

\section{CONCLUSION}

The present study emphasises the importance of severity scoring system like APACHE II in the management of critical illnesses like perforation peritonitis. We have followed the APACHE II in categorising the patients and managing them accordingly. The mortality rate of $6.6 \%$ is very low as compared to other studies. This signifies the importance of APACHE II scoring. We conclude that APACHE II should be included in guidelines for managing the perforation peritonitis cases.

\section{KEYWORDS}

Ileal Perforation, Ileostomy, APACHE II.

HOW TO CITE THIS ARTICLE: Agrawal G, Mittal M, Agrawal A, et al. Management of ileal perforation using APACHE - II scoring: a prospective study. J. Evolution Med. Dent. Sci. 2016;5(72):5281-5284, DOI: 10.14260/jemds/2016/1197

\section{INTRODUCTION}

Peritonitis resulting from small bowel perforation is a frequently encountered surgical problem in India. A review of literature indicates a very high mortality associated with this condition in spite of advances in treatment. ${ }^{1}$ Severity scoring is a valuable tool for assessing the severity of acute illness and thereby deciding the management strategy.

Financial or Other, Competing Interest: None.

Submission 30-07-2016, Peer Review 23-08-2016,

Acceptance 31-08-2016, Published 08-09-2016.

Corresponding Author:

Dr. Megha Mittal,

Opposite Old High Court, Lashkar,

E-mail:drgauravagr1@gmail.com

DOI: $10.14260 /$ jemds $/ 2016 / 1197$
Acute Physiology and Chronic Health Evaluation (APACHE - II) system is the best available method of risk stratification in intra-abdominal infection. ${ }^{2}$

The high mortality rate in patients with ileal perforation appears to be a function of the disease process rather than the means of treatment. The management of ileal perforation has been a subject of controversy. Operative treatment has been generally accepted as the treatment of choice, but the choice of procedure continues to be debated. ${ }^{3}$

\section{AIMS AND OBJECTIVES}

In this we will study the patient factors responsible for poor outcome, independent of or in association with APACHE II scoring. We will compare the outcomes of different methods of treatment. 


\section{REVIEW OF LITERATURE}

Our ability to extend and maintain life in the face of critical illness continues to improve as our diagnostic and therapeutic armamentarium becomes increasingly more advanced.

The reliable classification of the severity of illness is needed not only to predict prognosis, but also to evaluate and compare the results of different treatment regimens.

Currently, no ideal and generally accepted scoring system exists to determine the prognosis of peritonitis and intraabdominal sepsis. In multivariate analysis, only the APACHE II score contributed independently to the prediction of outcome. APACHE II system has been validated in large independent patient population and it has been used in several studies. ${ }^{4,5,6}$

\section{Advantages of APACHE II Scoring}

1. It is reliable and validated.

2. It is objective.

3. It is composed of information that is independent of diagnostic criteria.

4. It is composed of information that can be obtained prior to treatment and is therefore independent of treatment.

5. It has a large range of score with small increments, each of which contributes to the risk.

6. The score value can be translated into a mortality risk level.

Stratification by APACHE II score and distribution of risks depending on the number of patients in the study, they can be grouped into any number of strata by APACHE II score value. Smaller studies can be divided into 3 groups, forming low (010 points), intermediate (11-20) and high (21+) risk groups.

\section{MATERIAL AND METHODS}

This is a prospective study of 60 patients of surgically verified ileal perforation treated in J.A. Group of Hospitals, Gwalior, during 1.08.2005 to 31.07.2006.

The patients were categorised into three risk groups that is low risk, intermediate risk and high risk according to APACHE II scoring system (Table 1).

The low risk group were managed by surgery without fecal diversion (ileostomy). The intermediate risks were managed by surgery with faecal diversion (ileostomy). Since in high risk group patients could not undergo immediate laparotomy, they were managed medically first and then subjected to further management.

\section{OBSERVATIONS}

APACHE II score provides the extent of physiology derangement and preadmission chronic health of a patient with intra-abdominal sepsis. Thirty patients $(50 \%)$ had score below 10 (low risk group). Simple closure of perforation was done in 24 patients and resection anastomosis was done in 6 patients. Twenty six patients had a score in between 11-20 (Intermediate risk group). In all of them ileostomy with distal mucus fistula was made. All of them recovered satisfactorily. Four patients had a score of more than 20 (High risk group). In all of them, bilateral flank drainage was done under local anaesthesia. All of them died over a period of few days.

In low risk group the decision to perform resection anastomosis was based on, if the patient had:
1. Multiple perforations.

2. Perforation involving more than half circumference of bowel.

3. Adjacent unhealthy segment of bowel.

4. Strictorous segment.

Main post-operative complications were wound infection $43.3 \%$ and burst abdomen $23 \%$. Biopsy of ileal segment was performed in 46 cases. Thirty cases (65.21\%) showed acute enteritis, 12 cases $(26.08 \%)$ showed chronic nonspecific inflammation and 4 cases (8.69\%) showed epithelioid granuloma with caseation.

\section{DISCUSSION}

Most surgeons agree that the treatment of ileal perforation should be surgery, as this eliminates peritoneal soiling and endotoxaemia. There is, however, no uniformity of opinion as to the extent of surgery and several procedures ranging from simple closure of the perforation, wedge excision and anastomosis or segmental resection and anastomosis to ileostomy with mucus fistula. $(7,8,9,10,11)$

In the present study, different operative procedures were performed according to the severity of illness. Simple closure of perforation was done in 24 patients (40\%) with APACHE II score of $0-10$. These patients have single perforation with minimal peritoneal contamination. In 6 patient's resection and anastomosis was performed because of multiple perforations or single perforation involving more than half of bowel circumference or when the bowel was considered unhealthy for simple closure. Recovery was smooth in all these patients. In 26 patients with APACHE II score of 11-20, ileostomy with mucus fistula was made. All these patients recovered well. In 4 patients APACHE II score was more than 21, all of them died. All these results were comparable to other studies by Ourin,(7) Welch TP,(8) Kim JP,(9) Mulligan TO(10) and Gibney EJ.(11)

In present study, the aetiology was considered to be chronic inflammation and it was tuberculosis in $8.69 \%$.

In a study by Nadkarni et al,(12) the cause of perforation was difficult to establish in $56.6 \%$ patients and they were termed nonspecific. They concluded that the prognosis directly relates to the degree of septicaemia, which depends on the resistance of organism, degree of peritoneal contamination and delay in manifestation. Patients with advanced septicaemia usually die in spite of any treatment given.

In the present study, the mortality rate was $6.6 \%$ as compared to $9.5 \%$ in a study by Singh KP et al,(13) $21.2 \%$ in a study by Eustache and Kreis(14) and $30 \%$ in a study by Eggleston and Santoshi.(15)

\section{CONCLUSION}

The present study emphasises the importance of severity scoring system like APACHE II in the management of critical illnesses like perforation peritonitis. We have followed the APACHE II in categorising the patients and managing them accordingly. The mortality rate of $6.6 \%$ is very low as compared to other studies. This signifies the importance of APACHE II scoring. We conclude that APACHE II should be included in guidelines for managing the perforation peritonitis cases. 
The APACHE II Severity of Disease Classification System

\begin{tabular}{|c|c|c|c|c|c|c|c|c|c|}
\hline $\begin{array}{c}\text { Physiologic } \\
\text { Variable }\end{array}$ & +4 & +3 & +2 & +1 & 0 & +1 & +2 & +3 & +4 \\
\hline $\begin{array}{c}\text { Temperature - } \\
\text { rectal }\left({ }^{\circ} \mathrm{C}\right)\end{array}$ & $\geq 41$ & $39-40.9$ & & $38.5-38.9$ & $36-38.4$ & $34-35.9$ & $32-33.9$ & $30-31.9$ & $\leq 29.9$ \\
\hline $\begin{array}{c}\text { Mean Arterial } \\
\text { Pressure }(\mathrm{mm} \mathrm{Hg})\end{array}$ & $\geq 160$ & $130-159$ & $110-129$ & & $70-109$ & & $50-69$ & & $\leq 49$ \\
\hline Heart Rate & $\geq 180$ & $140-179$ & $110-139$ & & $70-109$ & & $55-69$ & $40-54$ & $\leq 39$ \\
\hline $\begin{array}{l}\text { Respiratory Rate } \\
\text { (nonventilated or } \\
\text { ventilated) }\end{array}$ & $\geq 50$ & $35-49$ & & $25-34$ & $12-24$ & $10-11$ & $6-9$ & & $\leq 5$ \\
\hline \multirow{2}{*}{$\begin{array}{c}\begin{array}{c}\text { Oxygenation } \\
(\mathrm{mmHg})\end{array} \\
\text { a. } \mathrm{FiO}_{2}>0,5 \text { use } \mathrm{A}-\mathrm{aDO}_{2} \\
\text { b. } \mathrm{FiO}_{2}<0,5 \text { use } \mathrm{PaO}_{2}\end{array}$} & a $\geq 500$ & $350-499$ & $200-349$ & & $<200$ & & & & \\
\hline & \multicolumn{4}{|l|}{ b } & $>70$ & $61-70$ & & $55-60$ & $<55$ \\
\hline Arterial pH & $\geq 7.7$ & $7.6-7.69$ & & $7.5-7.59$ & $7.33-7.49$ & & $7.25-7.32$ & $7.15-7.24$ & $<7.15$ \\
\hline $\begin{array}{c}\text { Serum Sodium } \\
(\mathrm{mmol} /)\end{array}$ & $\geq 180$ & $160-179$ & $155-159$ & $150-154$ & $130-149$ & & $120-129$ & $111-119$ & $\leq 110$ \\
\hline $\begin{array}{c}\text { Serum Potassium } \\
(\mathrm{mmol} /)\end{array}$ & $\geq 7$ & $6-6.9$ & & $5.5-5.9$ & $3.5-5.4$ & $3-3.4$ & $2.5-2.9$ & & $<2.5$ \\
\hline $\begin{array}{l}\text { Serum Creatinine } \\
\text { (mg/dl, Double point } \\
\text { score for acute renal } \\
\text { failure) } \\
\end{array}$ & $\geq 3.5$ & $2-3.4$ & $1.5-1.9$ & & $0.6-1.4$ & & $<0.6$ & & \\
\hline Hematocrit (\%) & $\geq 60$ & & $50-59.9$ & $46-49.9$ & $30-45.9$ & & $20-29.9$ & & $<20$ \\
\hline 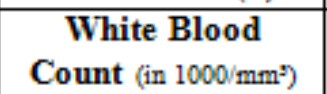 & $\geq 40$ & & $20-39.9$ & $15-19.9$ & $3-14.9$ & & $1-2.9$ & & $<1$ \\
\hline $\begin{array}{l}\text { Glasgow-Coma- } \\
\text { Scale (GCS) }\end{array}$ & \multicolumn{9}{|c|}{ Score $=15$ minus actual GCS } \\
\hline $\begin{array}{c}\text { Serum } \mathrm{HCO}_{3} \\
\text { (venous, } \mathrm{mmol} / \text {, use if no } \\
\mathrm{ABG} \text { ) }\end{array}$ & $\geq 52$ & $41-51.9$ & & $32-40.9$ & $22-31.9$ & & $18-21.9$ & $15-17.9$ & $<15$ \\
\hline $\begin{array}{c}\text { A = Total Acute } \\
\text { Physiology Score } \\
\text { APS }\end{array}$ & \multicolumn{9}{|c|}{ Sum of the 12 individual variable points } \\
\hline B = Age Points & \multicolumn{9}{|c|}{$\mathrm{C}=$ Chronic Health Points } \\
\hline $\begin{array}{ll}44 \text { years } & 0 \text { points } \\
45-54 \text { years } & 2 \text { points } \\
55-64 \text { years } & 3 \text { points } \\
65-74 \text { years } & 5 \text { points } \\
\geq 75 \text { years } & 6 \text { points }\end{array}$ & $\begin{array}{l}\text { If the } \\
\text { immun } \\
\text { a. } \\
\text { b. }\end{array}$ & $\begin{array}{l}\text { patient } \\
\text { compron } \\
\text { For nonop } \\
\text { For electiv }\end{array}$ & $\begin{array}{l}\text { has a } \\
\text { ised assi: } \\
\text { rative or en } \\
\text { postoperat }\end{array}$ & $\begin{array}{l}\text { istory } \\
\text { h points a } \\
\text { ergency pos } \\
\text { ve patients }\end{array}$ & $\begin{array}{l}\text { severe } \\
\text { follows: } \\
2 \text { points }\end{array}$ & nts -5 po & stem in & ufficienc & or is \\
\hline
\end{tabular}

(From: Knaus WA, Draper EA, Wagner DP, Zimmerman JE. APACHE II: a severity of disease classification system. Crit Care Med 1985;13(10):818-29)

\section{REFERENCES}

1. Dickson JA, Cole GJ. Perforation of the terminal ileum: a review of 38 cases. Brit J Surg 1964:51:893-7.

2. Knaus WA, Draper EA, Wagner DP, et al. APACHE II: a severity of disease classification system. Crit Care Med 1985;13(10):818-29.

3. Chouhan MK, Pande SK. Typhoid enteric perforation. Br J Surg 1982;69(3):173-5.

4. Dellinger EP, Wertz MJ, Meakins JL, et al. Surgical infection stratification system for intra-abdominal infection: multicenter trial. Arch Surg 1985;120(1):21-9.
5. Skau T, Nystrom PO, Carlsson C. Severity of illness in intra-abdominal infections: a comparison of two indexes. Arch Surg 1985;120(2):152-8.

6. Bohnen JM, Mustard RA, Oxholm SE, et al. APACHE II score and abdominal sepsis: a prospective study. Arch Surg 1988;123(2):225-9.

7. Olurin EO, Ajay 00, Bohrer SP. Typhoid perforations. J R Coll Surg Edinb 1972;17(6):353-63.

8. Welch TP, Martin NC. Surgical treatment of typhoid perforation. Lancet 1975;1(7915):1078-80.

9. Kim JP, Oh SK, Jarett F. Management of ileal perforation due to typhoid fever. Ann Surg 1975;181(1):88-91. 
10. Mulligan TO. The treatment of typhoid perforation of the ileum. J R Coll Surg Edinb 1972;17(6):364-8.

11. Gibney EJ. Typhoid perforation. Br J Surg 1989;76(9): 887-9.

12. Nadkarni KM, Shetty SD, Kagzi RS, et al. Small bowel perforations. A study of 32 cases. Arch Surg 1981;116(1):53-7.
13. Singh KP, Kuldip S, Kohli JS. Choice of surgical procedure in typhoid perforation: experience in 42 cases. J Indian Med Assoc 1991;89(9):255-6.

14. Eustache JM, Kreis DJ. Typhoid perforation of intestine. Arch Surg 1983;118(11):1269-71.

15. Eggleston FC, Santoshi B, Singh CM. Typhoid perforation of the bowel experiences in 78 cases. Ann Surg 1979;190(1):31-5. 